I Universidade de Brasília (UnB), Instituto de Ciências Sociais, Departamento de Antropologia, Brasília, DF, Brasil andreaslobo@yahoo.com.br

\title{
ÁFRICA... MAS NÃO MUITO! \\ TURISMO E AFRICANIDADE EM CABO VERDE
}

O presente artigo explora algumas imagens de África que permeiam o que poderíamos denominar genericamente imaginário ocidental. ${ }^{\mp} \mathrm{O}$ objetivo é refletir sobre as representações acerca do continente construídas por outsiders e como essas têm afetado autorrepresentações e processos. Mais especificamente, reflito sobre os sentidos de africanidade (re)elaborados na relação entre cabo-verdianos e turistas europeus que se deslocam para o arquipélago em busca de experiências africanas em um ambiente dito calmo, paradisíaco, exótico e tropical. Tais categorias, que permeiam os folders, sites e revistas de turismo no arquipélago, são analisadas como formas de representação e de autorrepresentação nesse contexto relacional que a viagem turística produz.

Cabo Verde é um cenário interessante para pensar tais questões, uma vez que sua africanidade é, por si só, um tema de disputa. Diversos autores têm abordado as ambiguidades, tensões e estratégias presentes na elaboração da identidade dos ilhéus com reflexões e posicionamentos sobre as oscilações entre as duas matrizes, a europeia e a africana, ambas bases da formação social crioula (Trajano Filho, 2003; Furtado, 2013; Anjos, 2003, Vasconcelos, 2007). Tais pesquisadores, cada um a sua maneira, ressaltam os processos de instrumentalização da caboverdianidade ou crioulidade que, a depender do período histórico, interesse ou lugar de fala, enfatizariam a matriz africana ou europeia, instrumentalizando-as. Nesse movimento pendular, a balança pesaria quase sempre para processos de "desafricanização da nação", de um afastamento material e simbólico do continente africano (Anjos, 2003; Furtado, 2013). 
Minha contribuição para esse debate consiste em demonstrar que as imagens construídas cultural e contextualmente pelos sujeitos sociais sobre Cabo Verde enquanto África podem estar em conflito, mas não necessariamente em oposição, sendo a africanidade acionada estrategicamente. Um olhar atento sobre as configurações que o turismo tem assumido nas ilhas de Cabo Verde pode ser um caminho interessante para revelar a complexidade dessa questão para além das arenas do debate intelectual e dos discursos políticos em torno da nação Cabo Verde. Centrar-me-ei nas estratégias de construção de (auto)imagens desse arquipélago africano no mercado turístico europeu, como cenário de beleza e tranquilidade ímpar, mas com uma pitada de exotismo no estilo "África".

O continente africano é um dos roteiros do exótico quando se trata do turismo no sentido norte-sul. Esse fluxo tem sido foco de um conjunto de análises que exploram práticas e significados do encontro entre os viajantes e os romantizados nativos ou locais (Kasfir, I999; Philips \& Steiner, I999; Bruner, I992; Comaroff \& Comaroff, 2009). Tais estudos têm demonstrado que o consumo turístico das práticas culturais mercantilizadas e não mercantilizadas é palco de uma tensão criativa entre representação e identidade com muitas variáveis, nas quais as representações para os outros e as autorrepresentações não são mutuamente exclusivas nem, muito menos, redutíveis a fórmulas dicotômicas empobrecedoras. Conforme salienta Bruner (2009: Io), de forma genérica o turismo contemporâneo envolve viagem de pessoas ocidentais em escala massiva às margens do império e às periferias da modernidade. Em resposta, os locais, juntamente com agentes e produtores turísticos, entendem os desejos do turista e retrabalham suas culturas indígenas para construir "novas culturas emergentes", especificamente para os turistas.

Em interessante artigo sobre representações do turismo internacional nas ciências sociais, Crick (I989: 329) insere no debate os destinos “'4 Ss' (sun, sex, sea and sand)". Ao refletir sobre os aspectos críticos e as demandas das viagens turísticas para o Terceiro Mundo, o autor chama atenção para os processos de perpetuação e reforço dos estereótipos, mais do que de sua superação. Tais (não)entendimentos do outro ocorreriam em ambas as vias, pois, se o turismo comodifica culturas, os nativos também categorizam os estrangeiros como recursos ou mesmo como estorvos, em vez de pessoas.

Para os autores citados as imagens sobre África e outros destinos enquanto espaços do exótico são alimentadas a partir de conexões e continuidades com as experiências coloniais. Uma rápida olhada para o universo cinematográfico nos serve de exemplo. Dentre tantas produções destaco duas, uma norte-americana e outra alemã, ambas ganhadoras de estatuetas do Oscar. $\mathrm{Na}$ década de 1980 temos o filme Out of Africa, ${ }^{2}$ um drama romântico que se passa no Quênia dos finais dos anos I9ıo, baseado na obra de Karen Blixen, escritora dinamarquesa que é a protagonista. O enredo aborda uma história dramática de amores e decepções entre ela e dois homens e entre ela e o Quênia. 
Meu segundo exemplo vem do cinema alemão, Nirgendwo in Afrika (Nowhere in Africa) ${ }^{3}$ também baseado em dados autobiográficos da autora Stefanie Zweigse. A história de uma família alemã de origem judia se passa nos anos I930, e o palco é também o Quênia, então colônia britânica que serviu como rota de fuga de algumas famílias de judeus no período da Segunda Guerra Mundial.

Ambas as histórias apresentam um perfil dramático que intercala sagas familiares e dramas amorosos em contextos coloniais que conectam europeus com o continente africano. Mais do que cenário ou palco no qual se desenrolam os dramas das personagens, a África surge como personagem central com sua natureza altamente perigosa, mas exuberante; e com seu povo, exótico, selvagem em sua cor e costumes, mas amável, doce, amigo e, quem sabe, sábio em sua selvageria e ingenuidade. Nas duas produções a África exótica é fortemente explorada em seus cenários deslumbrantes e em seus inúmeros perigos. O nativo que personifica a pureza e a postura servil entremeadas por uma amizade sincera também se torna ponto central nas duas narrativas. E nessa mistura dramática de dificuldades, medos, superações, negações e preconceitos surgem heroínas e seu amor profundo por um país (que simboliza um continente) que passam a chamar de seu e que aprendem a amar.

Trago essas imagens cinematográficas porque creio que elas sintetizam um tipo de construção sobre o continente que reflete o que muitos turistas buscam ao se dirigir a cenários africanos. Bruner (2009) analisa uma atração que é foco do turismo étnico no Quênia e que é intitulada Out of Africa Sundowner. O título da atração advém do filme aqui citado, que é exibido durante a viagem de avião na rota para a África. Segundo a brochura da agência de turismo que descreve a atração, "Standing at the precipice of the escarpment, the Sun setting low amidst Orange and Pink Sky, it is easy to see why Africa so inspired Karen Bliwen and Dennis Finch-Hatton" (Bruner, I992: 83). Conforme analisa o autor, a brochura convida o turista a experienciar o cenário não do ponto de vista do filme, dos atores, do livro ou da autora, mas do ponto de vista dos principais caracteres que compõem a história. "It is all make-believe" (Bruner, I992: 83). Complementando o cenário, os turistas, sentados, são cercados por um grupo masaai que apresenta uma dança tradicional e em seguida rompe as barreiras entre turistas e nativos convidando-os para dançar com eles. Os guerreiros masaai tornam-se, então, tourist-friendly.

Bruner e outros autores exploram muitas formas que o dito turismo étnico pode assumir, bem como sua complexidade enquanto espaço social de interação. Os caracteres aqui brevemente esboçados, tanto nos dois filmes quanto no exemplo etnográfico explorado por Bruner, parecem, entretanto, estar presentes com maior ou menor intensidade enquanto elementos constitutivos do tipo de turismo que embasa meus argumentos neste artigo: a natureza e o nativo exótico construídos por um conjunto de símbolos do que é (ou seria) a 
África. Símbolos que guardam muito de perspectivas construídas a partir de uma África colonial. ${ }^{4}$

Se Cabo Verde, ponto geográfico de minha análise, pode ser localizado como África (e assim é situado e explorado nos folders e sites turísticos), definitivamente não corresponde às imagens das savanas ou selvas africanas tão exploradas pelo cinema, pela literatura e pelas agências que vendem tours aos safáris ou a uma África tradicional que, afinal, não estaria tão perdida assim. Cabo Verde se apresenta ao turista mais como um destino sea, sun and sand, 5 ilhas com praias paradisíacas, de extensões intermináveis, desertas e inexploradas e, claro, prontas para ser descobertas. Em meio aos nativos não encontramos guerreiros e suas práticas imortalizadas em livros, filmes ou museus, mas um povo descrito como pacato, hospitaleiro, com a marca da tranquilidade e da abertura à amizade, "tão típica dos locais". Tudo isso com uma pitada de exotismo, pois aqui também há cultura, uma cultura mestiça, mas com "raízes autenticamente africanas" que se revelam no artesanato, ${ }^{6}$ na dança, na música e nos corpos dos ilhéus.

Todos esses ícones presentes nas construções de Cabo Verde para o turista refletem a tensão expressa na história do arquipélago, marcada pela relação pendular com o continente africano, ora de aproximação, ora de afastamento. Negação e afirmação de africanidade aparecem no discurso turístico revelando toda a complexidade que essa ambiguidade encerra. Ser e não ser África possibilita uma estratégia discursiva que atrai turistas interessados no exótico que uma África imaginada representa, mas sem correr os riscos que essa mesma imagem carrega em si. Afinal, como nos lembra Crick (I989: 327), se há algo que o turismo internacional requer é paz e estabilidade.

Dessa forma, produtores turísticos e população local exploram esse lugar in beetween no qual se insere Cabo Verde geográfica e culturalmente; seja quando exploram as características únicas do arquipélago, distante do continente, seja pela aproximação a esse, quando incorporam em suas descrições símbolos e signos de uma africanidade imaginada. Dessa forma, o discurso turístico satisfaz, a depender do contexto, as especificidades das ilhas e a "experiência africana” buscada pelos turistas. Tais estratégias serão o foco da análise que segue.

\section{CABO VERDE E O TURISMO}

No contexto do espaço atlântico tropical, o Estado cabo-verdiano passou a valorizar o turismo enquanto estratégia de desenvolvimento no princípio da década de I980. De maneira mais sistemática, é a partir de I986, com o Terceiro Plano Nacional de Desenvolvimento, que se verifica um cuidado especial reservado ao desenvolvimento turístico ligado à valorização da paisagem local. Em outros trabalhos (Lobo, 200I e 20I2), apontei para uma transformação no discurso sobre a paisagem no período pós-independência - de feia, hostil e sem atrativos para uma visão em que "o árido é belo". A mudança de perspectiva 
pode ser percebida nos programas de planejamento que passam a tratar o turismo como "a grande saída para Cabo Verde alcançar o rumo do desenvolvimento" (República de Cabo Verde, I997) e a convidar os investidores a explorar as belezas naturais e culturais das ilhas.

Nos documentos a influência benéfica do turismo se daria, imediatamente, em dois níveis: primeiro, traria desenvolvimento econômico, mais empregos e oportunidades de investimento para o país. Num segundo nível, por meio da valorização turística, se daria um processo de ressignificação da paisagem pelos próprios habitantes das ilhas. Tal tendência começou a ser contemplada no período pós-independência, mas só veio a ganhar força no final dos anos 1980 graças aos estrangeiros que assumiram o desafio dos primeiros investimentos.

José Maria Semedo, geógrafo e pesquisador cabo-verdiano, retrata em uma conversa o reflexo dessa mudança de perspectiva sobre a natureza das ilhas no caso da ilha da Boa Vista. ${ }^{7}$

Até fim dos anos 80 Boa Vista era uma ilha pobre e até maldiziam de suas dunas, que invadiam as portas das casas e ameaçavam a própria permanência da população nas vilas. Por todos os cantos do arquipélago, Boa Vista era conhecida como uma ilha perdida e desertificada pela areia. Hoje, afinal, as dunas são o maior recurso da ilha e ela é descrita como uma ilha com grandes potencialidades. Antes (por volta de 1977) brincavam com um aluno meu, boa-vistense, dizendo que o governo deveria vender Boa Vista para os russos e transferir seus pouco mais de 3.000 habitantes para São Felipe (na ilha de Santiago), assim Cabo Verde ganharia muito dinheiro e resolveria todos os seus problemas! Hoje ninguém pensa assim, muito pelo contrário, a secura e as dunas são potencialidades naturais e têm transformado Boa Vista numa ilha muito importante (José Maria Semedo, entrevista à autora).

Dessa forma, num contexto de valorização da aridez e do que Cabo Verde tem como maior recurso, o mar e as praias, ilhas como Sal, Boa Vista e Maio passaram a crescer em importância e a ser contempladas em um discurso nacional de desenvolvimento. Cada uma das dez ilhas que compõem o arquipélago, entretanto, apresenta percursos e atrativos diferenciados e, com suas particularidades, atraem investidores estrangeiros em momentos distintos da história recente do arquipélago.

Em um dos poucos trabalhos que abordam a questão turística em Cabo Verde, Santos (2009) ${ }^{8}$ sistematiza dados que muito nos informam sobre os resultados desse processo de incorporação do turismo como via para o desenvolvimento do arquipélago. Tendo o governo assumido esse setor como estratégico desde o pós-independência, o que se colhe hoje é que "em Cabo Verde o turismo constitui a principal fonte de riqueza nacional, representando cerca de $20 \%$ do PIB, e é um setor para o qual se canalizam mais de $90 \%$ dos investimentos externos. Em 2008 entraram no país 333.354 turistas, num contraste gritante com os 52.000 de dez anos antes" (Santos, 2009: I). ${ }^{9}$ 
Os anos 2000 são marcados por uma passagem do turismo enquanto estratégia presente nos documentos governamentais para a materialização dos investimentos. Um exemplo está no número de aeroportos internacionais: até 2005 o país contava apenas com o Aeroporto Internacional da ilha do Sal; hoje já são quatro, localizados nas ilhas do Sal, Boa Vista, Santiago e São Vicente. Como consequência cresce a diversidade de destinos internacionais com conexão direta para as ilhas, bem como o número de operadoras aéreas e de turismo que "vendem" as belezas de Cabo Verde no exterior.

O crescimento vertiginoso ocorre graças aos investimentos, em sua maioria por parte de europeus e suas redes de hotelaria que se instalam nas ilhas. A abertura e os incentivos fiscais oferecidos pelo governo cabo-verdiano, somados às condições econômicas e políticas do país, considerando o contexto dos demais países da África Ocidental no qual se insere, têm atraído investidores italianos, portugueses, alemães. Por fim, é preciso considerar também sua localização geográfica como fator atrativo tanto para os investidores quanto para os visitantes.

No que diz respeito aos hóspedes, em 2008 foram os turistas oriundos do Reino Unido, Itália e Portugal os mais representativos no arquipélago, totalizando $23,2 \%$, I $8,6 \%$, I 4,9\% dos pernoites, respectivamente (INE, s.d.a). Das ilhas que se destacam como destino, temos a ilha do Sal ainda em primeiro lugar, seguida da ilha da Boa Vista (que a partir de 2008 se encaminha para assumir o posto de principal destino, sendo foco de um boom de investimentos), Santiago e São Vicente, sendo as ilhas de Santo Antão, Fogo e Maio também bastante procuradas.

Quando voltamos nossos olhares para a dimensão dos investimentos no setor reforçamos a constatação do crescimento rápido. Santos (2009: 43) apresenta os seguintes dados:

Estima-se que daqui a 3/4 anos o país conte com cerca de 16 mil camas, representando cerca de 17 mil postos de trabalho. Hotéis, resorts de luxo, marinas, aquaparques e projetos de imobiliária turística vão preencher as principais orlas marítimas do país. No Sal, estão já aprovados nove grandes projetos a concluir em Io anos, num total de mais de 2.500 hectares construídos. Para S. Vicente está projetado um empreendimento de luxo que representa o maior investimento turístico alguma vez feito em Cabo Verde. O Cesária Resort irá custar perto de um bilhão e meio de euros para comportar cerca de 35 mil pessoas e mais de 3.000 postos de trabalho diretos.

Complementando o quadro, no próximo tópico analisarei os investimentos dos últimos 15 anos na ilha da Boa Vista. ${ }^{\text {Io }}$ Dada sua proximidade da ilha do Sal (apenas I5 minutos de avião) e suas características paisagísticas, não tardou muito para Boa Vista ser conhecida pelos turistas e, consequentemente, por investidores. A ilha foi construída como polo turístico promissor por ter potencial maior que o da ilha do Sal devido à extensão de sua costa e sua paisagem mais diversa. Enquanto os investimentos turísticos na primeira estão praticamente restritos à praia de Santa Maria, Boa Vista oferece inúmeras opções 
de praias ao longo de sua costa, além das dunas e das pequenas vilas dispostas em pontos diferenciados da paisagem. Além dos fatores naturais, observaremos a construção da cultura boa-vistense como fator de atração de visitantes e a agregação estratégica do artesanato trazido por imigrantes da costa africana para ser vendido como suvenir aos turistas.

\section{DESCOBERTA E ASCENSÃO DE UM NOVO PARAÍSO TURÍSTICO EM CABO VERDE: A ILHA FANTÁSTICA ${ }^{11}$}

Boa Vista é a primeira ilha onde o sol derrama os seus raios dourados, por ser a mais oriental do arquipélago de Cabo Verde e a mais próxima da costa ocidental africana.

Do seu achamento pelas Caravelas de António de Noli, a 3 de maio de I460, passando pelo seu povoamento até meados do século XIX, a ilha conheceu períodos áureos de sua história. Com efeito, empório das ilhas de Barlavento, no século XIX, Boa Vista veria sua Igreja Matriz, a de S. Roque do Rabil, indicada para Catedral da Colônia, tendo em conta seu crescimento em riqueza, em edifícios de tipo europeu e em importância social, teria o privilégio de ser proposta para capital de Cabo Verde.

O destino quis que a ilha, ainda no século XIX, se destronasse e se calasse perante suas então rivais, S. Vicente e Santiago, e se resumisse, lembrando o poeta boa-vistense Daniel Felipe, a um 'ponto anônimo da carta', à espera, do mioceno a esta parte, de um príncipe encantado para a desvendar naquilo que tem de mais genuíno, a natureza, e de mais nobre, a sua gente.

É com recobrado júbilo que hoje ouvimos falar com mais frequência da ilha. Será o prelúdio da chegada do príncipe encantado?

A ilha da Boa Vista espera por ti, ó príncipe. Espera-te nua, donzela ainda, nas suas praias qual branca de neve, onde a vista se perde no infinito do círculo da ilha e as águas de um verde claro e azul transportam-se para o merecido repouso da longa viagem.

É príncipe: ali está ela, oferecendo-te a paz nunca conturbada, debaixo de um clima ameno e reconfortante durante todos os dias do ano, a uma temperatura média a oscilar entre os 22 graus e os 25 graus centígrados.

Além das praias e dunas, o mais belo da ilha é a sua gente, com sua particular e genuína morabeza, tanto no acolhimento quanto no fino trato (Lima, I999). ${ }^{\mathrm{I} 2}$

A ilha da Boa Vista tem sido palco desse fluxo turístico que se intensifica a cada ano desde finais dos anos I990. Conforme relato de José Maria Semedo, em menos de dez anos Boa Vista saiu do anonimato e da condição de ilha periférica para ganhar lugar de destaque no discurso de valorização nacional em face do mundo externo. Assim como a africanidade de Santiago e a boemia de São Vicente, as belezas naturais da Boa Vista teriam sido incorporadas nesse discurso de nação que encara o turismo como "a grande saída para o desenvolvimento".

Foi no começo dos anos I 990 que começaram os investimentos visando 

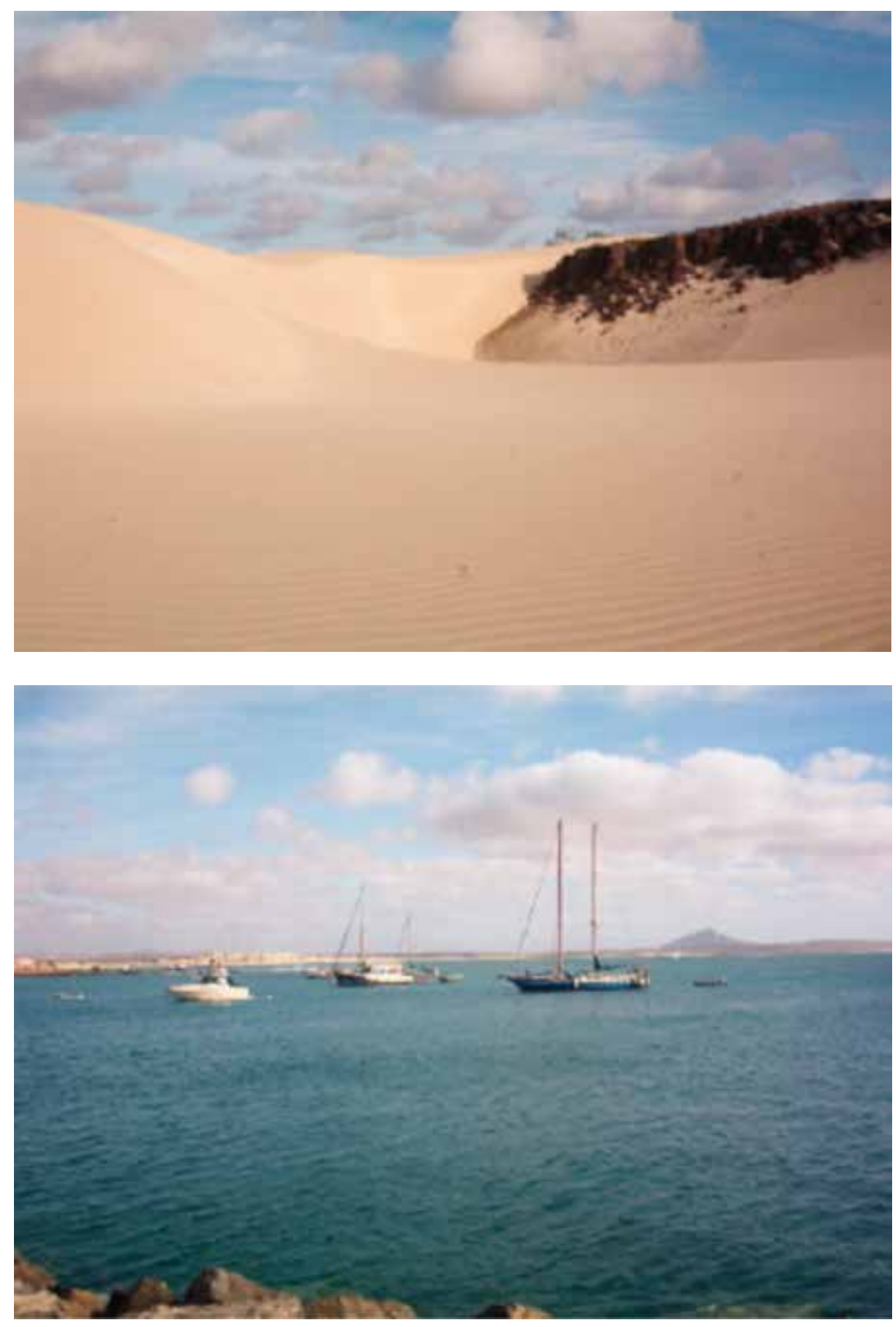

Deserto de Viana e Praia de Chaves Fotos de Mario Costa 
à criação de uma infraestrutura para o recebimento de turistas. O primeiro hotel foi construído no centro da vila de Sal-Rei por um francês que já estava sediado na ilha do Sal e que dizia ter encontrado na Boa Vista "o melhor lugar do mundo para viver". A construção do Hotel Dunas possibilitou o fluxo de italianos e outros europeus, fazendo crescer o interesse dos primeiros em investir no local. Por sua vez, o governo facilitava a tais investidores a compra de terrenos e disponibilizava a pouca estrutura existente para a construção dos investimentos.

A virada turística começa a dar seus sinais em I994. O marco foi a construção do hotel Marine Club por italianos na praia de Cabral, vizinha à vila de Sal-Rei. Ainda no mesmo período, mais precisamente em I996, dois outros complexos foram viabilizados também por italianos, o Hotel Estoril Beach, logo à entrada de Sal-Rei, e o Village de Chaves, na praia de mesmo nome, localizada próximo à vila do Rabil. Em I998, Boa Vista já recebia os primeiros fluxos de turistas italianos, o que incentivou a pequena elite local (formada prioritariamente por ex-emigrantes) a construir pousadas, restaurantes tradicionais e mercearias que pudessem oferecer serviços ao turista interessado no modo de vida local.

Após esse primeiro ciclo de investimentos, em que foram construídos a um só tempo cerca de cinco unidades hoteleiras de médio porte, os esforços se concentraram na melhoria e na ampliação de tais estruturas, bem como na criação de outras que complementam e prestam serviços aos turistas, por exemplo, escolas de windsurf e mergulho, lanchonetes, espaços com internet, discotecas, lojas de artesanato, sorveterias, centros de aluguel de carros, motos de areia e bicicletas. Ao governo local coube a tarefa de tratar dos espaços públicos das vilas com a reforma de praças e fachadas das casas, bem como investir na capacitação de jovens e na criação de um Centro de Atendimento ao Turista.

Em 2002, começou uma nova fase de investimentos com a construção de dois complexos hoteleiros, os chamados resorts, ambos distantes de Sal-Rei e com estrutura para hóspedes que desejam conforto e pouco contato com a população local. A propaganda em torno de tais complexos turísticos centrava no fato de serem os primeiros resorts cinco estrelas de Cabo Verde (cada um com mais de 700 leitos).

Tais investimentos foram inaugurados ao longo de 2008 e 2009 em praias distantes da vila principal e têm como proposta o turismo de resort com amplo espaço de lazer e capacidade de carga que varia entre 300 e 800 quartos. Os três principais empreendimentos fazem parte de grandes redes de hotelaria com renome internacional; as redes RIU e Iberostar são exemplos. Paralelamente há um conjunto de empreendimentos imobiliários em curso para construção de condomínios à beira-mar, visando também ao mercado europeu.

Os governos, local e nacional, se apropriam dessa nova fase como sendo o turning point na história da Boa Vista, passando de ilha periférica e sem importância para assumir o lugar de uma das principais ilhas do arquipélago, 
movimentando a economia nacional. Em 2005, o então primeiro ministro do país, José Maria Neves, estimava que até 2020 atingir-se-ia a capacidade de hospedagem de 30.000 leitos, estimativa por muitos considerada absurda. Fato é que a previsão não parece estar muito longe de se concretizar.

Na perspectiva da população local, e mesmo dos primeiros investidores italianos que já vivem na ilha há cerca de 20 anos, tudo aconteceu de forma muito rápida. O discurso é de que as pessoas ainda estão sob o impacto do boom de desenvolvimento na ilha e ainda não sabem como lidar com isso. Diante do crescimento vertiginoso, há um clima de preocupação geral e um misto de sentimentos ambíguos sobre o que o turismo tem trazido para a vida local e o que será do futuro da ilha. Porém, se a nova condição impõe preocupações, a população local não tem assistido a tudo isso passivamente. Dadas as características dos investimentos - hotéis afastados das povoações, localizados em praias desertas e com um sistema all inclusive, que envolve os turistas em bolhas ou enclaves turísticos (Rovisco, 20I7) - é sabido que os locais são amplamente excluídos e, quando envolvidos, o são em alguma condição periférica. Os jovens, entretanto, parecem participar dessa nova dinâmica, ou como trabalhadores das redes de hotelaria, restaurantes e bares, ou como protagonistas em pequenos empreendimentos que exploram, sobretudo, as especificidades naturais e culturais que atraem os visitantes.

Os turistas são predominantemente de origem europeia, sendo a maioria da Itália, seguida por alemães, franceses e ingleses. Um grupo significativo é composto por pessoas de alto poder aquisitivo que seguem em grupos organizados e se hospedam nos luxuosos hotéis e resorts, outros são viajantes independentes que ficam nos estabelecimentos dentro da vila. Os primeiros já têm os dias preenchidos num cronograma proposto pelas agências de viagens na Europa e no sistema all inclusive. Os demais preferem interagir no dia a dia da ilha, comendo a comida local, hospedando-se em pousadas, em busca de uma experiência mais íntima.

Um investidor italiano que chegou à ilha em I997 para trabalhar no Marine Club e em 2005 administrava dois pequenos hotéis na vila de Sal-Rei, afirma haver dois tipos de turistas que procuram a Boa Vista:

Primeiro tem os viajantes, com passaporte todo carimbado, em busca do exótico. Estes são mais espertos e sabem o que vão encontrar na África. Não reclamam se não encontram uma comida em condições, estão interessados na aventura, no contato com a população local e na vida tradicional. São europeus de maior poder aquisitivo, que têm mais liberdade para viajar em baixa estação e que vêm em qualquer época do ano. No começo, estes eram os únicos que procuravam a Boa Vista.

Agora já temos um segundo grupo que começou a chegar em 200I, os turistas de massa. Eles surgem em consequência de mais companhias de turismo interessadas na Boa Vista, o que leva a mais concorrência e a baixa de preços. Estes turistas têm o passaporte limpo, geralmente, estão em sua primeira viagem e 
não estão interessados na vida local, mas em um bom hotel com praia, piscina e o contato com os locais acontece nos espetáculos dos hotéis e nas atividades organizadas dentro desses espaços. Eles vão do aeroporto para o hotel, não vão para a vila e não são autônomos, querem a comida que comem na Itália e não abrem mão do conforto.

A conversa com esse investidor sintetiza diversos elementos presentes na dinâmica turística das ilhas. O primeiro aspecto nos leva a um dos dois tipos de turistas que se dirigem ao arquipélago, o turista de resort, um personagem que carrega o estigma da busca de uma experiência não autêntica, uma vez que procura um destino exótico, mas na segurança do hotel. Bruner (2009), ao analisar o turismo étnico de luxo, nos lembra que hotéis não são apenas lugares para dormir, são atrações turísticas em si. Os hotéis quatro e cinco estrelas da ilha da Boa Vista, sem dúvida, se encaixam nessa categoria. Um passeio pelos sites é suficiente para nos demonstrar como a combinação do luxo com um ambiente inusitado é explorada. Vamos a alguns exemplos:

Se sempre sonhou ver a fascinante paisagem das áreas vulcânicas de Boa Vista, Cabo Verde, no meio do oceano Atlântico, o novo complexo ClubHotel Riu Karamboa (Tudo Incluído 24h) dá-lhe essa oportunidade. O ClubHotel Karamboa, situado numa infinita praia de areia branca com água cristalina, oferece as melhores vistas desta área com dunas que beijam a costa.

Considerando a aparência desértica da região, é difícil acreditar que aquelas costas alguma vez estiveram cobertas por vegetação. Porém, recorrentes secas e uma fraca política agrícola reduziram Boa Vista e Cabo Verde a uma paisagem seca, quase lunar. No entanto, isso não impediu que a ilha esteja repleta de locais com praias espetaculares, tal como a praia das Tartarugas, praia Chaves, Santa Mónica e o cemitério de golfinhos. Não perca as várias excursões nas proximidades do ClubHotel. ${ }^{13}$

O Hotel Riu Touareg (Tudo Incluído 24h) situado em Boa Vista, Cabo Verde, oferece um serviço completo para garantir que a sua estadia neste hotel de 5 estrelas seja uma experiência inesquecível.

À noite, poderá dançar ao som dos melhores ritmos africanos na discoteca, ouvir música ao vivo, assistir a espetáculos ou simplesmente desfrutar da brisa de Cabo Verde no bar. No horizonte de Boa Vista e das suas irmãs cabo-verdianas, poderá apreciar uma paisagem seca, quase lunar, outrora coberta com vegetação que foi destruída pela seca. No entanto, a ilha está repleta de locais com praias espetaculares, tais como a praia das Tartarugas, praia Chaves, Santa Mónica e o cemitério de golfinhos. ${ }^{14}$

Características com atributos negativos - deserta, lunar, vulcânicas, secas - são combinadas com a inesperada exuberância de uma paisagem que, inusitadamente, se apresenta como espetacular e paradisíaca. Soma-se a isso a possibilidade de experienciar os ritmos africanos com música ao vivo e espetáculos de dança. Tudo vivido em ambientes cinco estrelas com muitas opções de lazer e serviços disponíveis aos hóspedes de todas as idades. Cada um des- 
ses complexos turísticos oferece, em média, 800 quartos e ampla área de lazer com piscinas, academias, áreas de massagem, jardins, bares, restaurantes etc. ${ }^{15}$

Esse turismo de resorts que se pretende um fluxo de massa nos permite explorar continuidades e descontinuidades do trânsito norte-sul. As pessoas parecem estar reproduzindo a velha posição de sujeitos coloniais que "exploram" e passeiam pelas paisagens locais, pelos nativos primitivos e pelas praias selvagens e paradisíacas. Nas palavras de Bruner (2009: I4), são "realeza" e esperam ser tratadas como tal. Por sua vez, os resorts parecem preencher essas expectativas a contento. Relembro ao leitor os elementos presentes nos dois filmes mencionados no início deste artigo, o cenário, os nativos e o rompimento de barreiras entre europeus e africanos. Como já dito, Bruner explora a permanência desses elementos no turismo étnico, continuidade observada por mim no contexto cabo-verdiano.

Este é um ponto central ao qual retornaremos mais adiante: representações correspondidas geram conforto aos turistas, e a capacidade de ler tais representações externas e, de certa forma, incorporá-las na autorrepresentação que será mercantilizada no contato turístico parece ser a chave encontrada em determinados locais para que o turismo se desenvolva.

Antes de seguir para esse aspecto do argumento, porém, quero retornar ao outro tipo de turista presente na fala de meu interlocutor, o turista que deseja interação, aventura e uma experiência genuinamente autêntica. Definido como aquele que tem o passaporte todo carimbado, o que deseja aventura e abre mão do conforto, esse tipo de viajante busca interação, e os locais também devem saber ler suas representações no sentido de lhes corresponder. É para esse turista que a principal vila da ilha, Sal-Rei, se prepara com pequenas pousadas no estilo Bed\&Breakfast, bares com música e dança tradicional, lojas de artesanato e agências locais de turismo que oferecem passeios e diversão conduzidos por guias locais.

Cada tipo, a sua maneira, afirma vivenciar experiências exóticas. São os últimos, porém, que criam vínculos com os locais, deixam a ilha com tristeza e levam na memória dias de pura magia. Segundo dados de uma agência turística italiana com sede na vila de Sal-Rei, mais da metade dos italianos interessados em interagir com a população local retornam duas ou três vezes à ilha para uma nova temporada de férias. O motivo principal é a "saudade que sentem dos amigos" que fizeram numa primeira visita, da alegria e dos bons momentos que viveram na ilha. Dos que retornam e recomendam uma temporada a amigos na Europa, as mulheres são a maioria.

Os atrativos naturais são o cartão de visita da Boa Vista, mas a experiência com a cultura local é o que parece deixar marcas. Um jornalista cabo-verdiano comenta que essa é uma "ilha com alma, a mesma que recebe quem a visita com hospitalidade que já não se encontra em todo o país”. Então, se as belezas naturais atraem para uma primeira visita, é a hospitalidade do boa-vistense que deixa saudades e faz o turista voltar. 
Mesmo aqueles que não estão em busca de interação com os locais encontram nos hotéis a receptividade dos funcionários, especialmente os "animadores". O grupo de animadores que trabalha nos hotéis é formado por moças e rapazes jovens e bonitos que têm a função de animar os hóspedes, ou seja, acompanhá-los nas refeições, nos passeios pelas praias, nas atividades esportivas e de lazer; são eles que dançam nas noites cabo-verdianas e acompanham os turistas nas investidas noturnas a danceterias e bares. A relação com esses jovens pode ser intensa e culminar em amizade ou relação amorosa. ${ }^{16}$

Enquanto os turistas de resorts têm uma experiência "controlada" com os locais, o outro interage mais intensamente com a população da vila, frequenta restaurantes locais, vai ao mercado, aos bares, faz passeios com os condutores (taxistas) que os guiam por excursões nas mais belas praias, tentam aprender palavras em crioulo, acabam por se juntar aos grupos de jovens nas noites de paródia (festas), chegando a visitar suas casas e conhecer as famílias. Esses turistas são caracterizados como pessoas simples, "brancos sem frescura". Nesse caso, o encontro vai além dos funcionários do hotel ou de um grupo que está mais próximo do ambiente preparado para receber o turista e chega a uma parcela da população que não está, necessariamente, em busca de envolvimento com outros.

$\mathrm{Na}$ enquete que realizei em $2005 \mathrm{com} 46$ italianos e italianas identificados pelos boa-vistenses como "turistas sem frescura", 28 estavam em sua segunda ou terceira visita à ilha e, daqueles que a visitavam pela primeira vez, I4 diziam querer retornar em outra oportunidade. As razões para o retorno eram sempre as mesmas: a ilha é um paraíso, as pessoas são amigas, e as memórias dos dias vividos são mágicas. Uma das informantes se dizia em busca de um lugar tranquilo para descansar do estresse da vida na Europa quando procurou Boa Vista pela primeira vez, mas acabou por encontrar muito mais, encontrou amigos e agora não podia mais passar um ano sem voltar à ilha para viver dias agradáveis (utiliza a expressão sab em crioulo para enfatizar seu sentimento).

O ponto comum nos dois grupos de visitantes é a descrição da temporada na Boa Vista como uma experiência única e mágica. Aqueles que retornam, entretanto, têm duas categorias marcando seu discurso de forma especial: além da magia da ilha, a disponibilidade da gente. Na visão desse turista que retorna ou que indica a ilha a amigos em seu país, a localidade encanta porque o boa-vistense é simpático e disponível. Além disso, é uma ilha particular, com magia que só ela tem. Esse tipo de discurso também é apropriado pelos agentes de viagens nos sites, folders e guias sobre o local.

Da população em geral, são os jovens os que mais se beneficiam do turismo. Para eles, o vínculo criado com italianos representa status e mais uma oportunidade possível de seguir para a emigração. A maioria deles quer entrar no mercado turístico como recepcionista, guia e, especialmente, como animador. Outros se organizam de forma mais independente, alugando carros, traba- 
lhando como taxistas, guias ou formando grupos de dança que se apresentam nos hotéis e restaurantes. Há ainda, os "especialistas" em frequentar os ambientes mais procurados por turistas na busca de algum tipo de aproximação. A população jovem local se beneficia do contato com o turista muito além da remuneração financeira, e isso é mais intenso para aqueles que trabalham como animadores. Além do dinheiro, eles recebem presentes e até a possibilidade de ir para o exterior levados por um deles.

Daniela é uma negra de 23 anos esguia e bela. Tem o cabelo sempre bem penteado em estilo africano, e suas roupas são cuidadosamente escolhidas para valorizar o corpo. Quando a conheci, trabalhava no Hotel Marine Club como animadora e, mesmo nas horas de folga, a encontrava acompanhada por um ou mais italianos e italianas. Daniela falava a língua com fluência e fazia bom uso de todos os seus atributos para conquistar a simpatia e a "amizade" dos visitantes. Apesar de reclamar algumas vezes dos "brancos" que estavam sempre a demandar sua companhia, me elencava as inúmeras vantagens do trabalho como animadora no hotel: as gorjetas, a convivência com pessoas diferentes, a possibilidade de sair da Boa Vista, os presentes que ganhava e a vida movimentada caracterizada pelo fato de não ter tempo para outras coisas, por viver cansada, e correndo entre casa, hotel e atividades com turistas. Além do trabalho no hotel era sempre convidada a participar das noites cabo-verdianas para desfilar trajes típicos, apresentar as danças tradicionais e, por fim, ensinar aos turistas alguns tipos de danças. ${ }^{17}$

A difusão de um estilo de vida tal como o de Daniela e de muitos outros jovens na faixa etária de 17 a 30 anos tem influenciado algumas dimensões interessantes do padrão de vida local. O primeiro aspecto é a tendência, entre a população mais jovem, de se fixar por mais tempo na ilha, dedicando-se aos trabalhos ligados ao turismo.$^{18} \mathrm{O}$ que, entretanto, mais nos interessa aqui é a construção de uma identidade local que atenda às expectativas que os turistas constroem ao buscar Cabo Verde como destino de férias. Como desenvolverei na próxima sessão, essa identidade mescla aspectos das ilhas como destinos típicos do paradisíaco com o exotismo característico de paisagens imaginadas; no caso aqui em análise, os atributos conectam hospitalidade, segurança e o exótico - e o pressuposto é de que tais atributos sejam "autênticos". Como afirma Urry (I990), o olhar do turista é construído pela diferença de formas não turísticas de experiência social. Tal olhar não é individualizado, mas socialmente elaborado em processos complexos de construção de um lugar como turístico graças a determinados atributos. Como tenho abordado aqui, não existe, porém, um único olhar turístico, pois ele varia de acordo com o grupo social, as trajetórias e o período histórico que condicionam a formação de preferência sobre o que ver e visitar (Santos, 2009: 49).

Antes de avançar, resta explorar dois dos elementos que conectam expectativas e reconfigurações identitárias: as ideias de exotismo e de "amizade". 


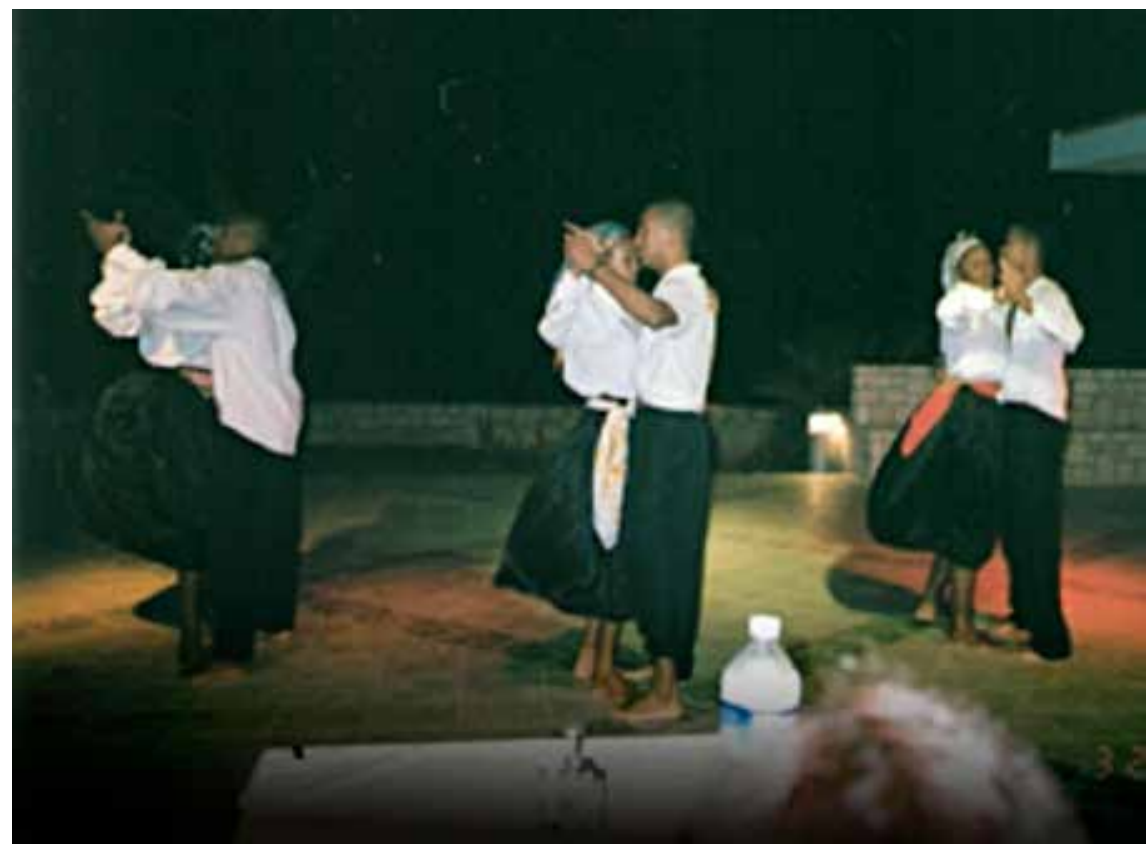

Apresentação de noite cabo-verdiana no Hotel Marine Club

Foto de Andréa Lobo

As imagens do exótico e do paradisíaco são fartamente exploradas no trecho que abre este item, escrito por Germano Lima, intelectual cabo-verdiano nascido em Boa Vista. No texto publicado na revista de bordo da TACV, ele realiza uma analogia entre a ilha e uma virgem que aguarda e se oferece ao príncipe encantado. A natureza paradisíaca e exótica parece guardar continuidade com o feminino à espera do explorador, do turista - continuidade explorada aqui também na relação entre jovens locais e os turistas com quem se relacionam. A categoria amigo, também amplamente utilizada para tratar da relação entre turistas e os locais, parece sintetizar o que o visitante imagina encontrar: uma simpatia genuína e uma "amizade natural das pessoas" em continuidade com a natureza paradisíaca do lugar. ${ }^{19}$

A combinação dos dois elementos, natureza paradisíaca e pessoas naturalmente "amigas", compõe um sentido de exótico que guarda continuidades claras com a experiência colonial trazidas aqui pelos filmes que apresento na primeira sessão. As representações de uma África colonial parecem se reproduzir não só para os turistas de resorts que resgatam a velha posição de sujeitos coloniais exploradores do exótico, mas também entre os turistas descolados que se aproximam dos locais e fazem "amigos". 
Ao fim e ao cabo, o que parece estar em questão é um jogo narrativo no qual as noções de paraíso, amizade e hospitalidade (morabeza) são vendidas como expressões naturais e autênticas para os turistas que, assim como os sujeitos coloniais de outrora, buscam vivenciar algo único em sua viagem. $\mathrm{Na}$ perspectiva de quem os recebe, como nos lembra Crick (I989: 329), não importa o quanto os folders falem de amizade natural das pessoas ou da natureza paradisíaca do lugar, de fato, generosidade tem pouco a ver com a provisão de serviços aos turistas, e os lugares que aparecem nas brochuras de viagem, no fundo não existem, são simulacros criados pela perspectiva de que se pode vender o paraíso. Porém, por mais que as autoimagens sejam performatizadas para "atender a expectativas" em uma lógica de mercado, acabam por se constituir em espaços de reconfigurações identitárias. Exploremos mais a fundo esse aspecto.

\section{ÁFRICA....MAS NÃO MUITO!}

[T] his is the archipelago of Cape Verde, natural heritage of rare beauty, made up of pristine white beaches and desert alternating with slices of green valleys that are gradually become(sic) an international tourist landmark for lovers of relaxation and untouched nature. The contact with the population in the smaller islands is one of the ways to discover the soul of the proud and dignified people of Cape Verdean. In Boa Vista you can breathe the magic of Africa, thanks to the boundless deserts, endless beaches and pristine oasis and is considered in itself island, pure and wild nature, in contrast with the friendliness of its 3.500 inhabitants concentrated for the most part in Sal Rei, the capital. Its appeal is to the places where time flows peacefully, when the hours are marked by the desires and not by the clock. ${ }^{20}$

Cape Verde is a challenging place. The islands are warm and sunny all year. The people are a unique race - part African, part Portuguese, part any race with the temerity to land in this isolated, wave-pummelled place since their discovery in the mid I5th-century. Their history, until late last century, was a bleak and moving one, and the people are infused with a poetry and musicality that reflects their melancholy past.

In summary, Cape Verde is not a nation for people who expect to be served a dream holiday on a plate. It's for people who have a little bit of the adventurer in them, who are curious about people and place, who will lap up the oddities that island life might throw at them. ${ }^{21}$

It's not just open ocean that separates Cape Verde from the rest of West Africa. Cool currents, for example, keep temperatures moderate, and a stable political and economic system help support West Africa's highest standard of living. The population, who represent varying degrees of African and Portuguese heritage, will seem exuberantly warm if you fly in straight from, say, Britain, but refreshingly low-key if you arrive from Lagos or Dakar. ${ }^{22,23}$ 
Uma vez que o primeiro contato que o turista tem com o local não é o local em si, mas uma representação dele feita pelo marketing turístico, passa a ser interessante refletir sobre esse processo de produção do local por especialistas que veiculam um discurso promocional do lugar turístico em linguagem publicitária.

Se por um lado os sites e guias apresentam as ilhas a partir de símbolos que nos remetem a uma experiência única, genuína e essencialmente cabo-verdiana - ilhas, praias de água cristalina, solo vulcânico, beleza rara, paraíso, nativos com uma mistura singular, calma, segura e atemporal -, por outro ampliam o escopo dessa experiência ímpar ao inseri-la em um contexto maior geográfica e culturalmente, a África. Cabo Verde então, é mais do que uma experiência singular, é um lugar no qual você pode respirar a "magia da África", afinal, estamos em um "fascinante país que se encontra a 50okm da costa ocidental africana". O portal oficial de turismo de Cabo Verde explora, ainda, uma faceta importante das ilhas africanas: a segurança de estar em África, mas em um país com uma história marcada pela estabilidade política e econômica, ou seja, ao marcar a oposição com o continente, onde imperaria a instabilidade política, afirma que Cabo verde é África na geografia, mas não o é na política.

As imagens produzidas sobre o arquipélago exploram, portanto, a ambiguidade que permeia a identidade do cabo-verdiano ao longo de sua história, a especificidade das ilhas, do povo e da cultura (graças ao processo de mestiçagem e crioulização) e a pertença ao continente africano. O jogo de aproximação e distanciamento com relação a uma experiência "genuinamente africana" assume nova forma, aquela que "vende" Cabo Verde como um produto turístico.

Porém, mais do que analisar os símbolos presentes no discurso publicitário que produzem Cabo Verde para um público externo, é fundamental refletir sobre a circularidade desse discurso. As imagens aqui apresentadas, embora destinadas ao exterior, são apropriadas pela população local no sentido de não frustrar as expectativas dos fregueses. É nesse processo circular de produção para fora e autoprodução identitária que vemos ressurgir a tensão criativa entre cabo-verdianidade e africanidade com novos elementos, na construção da natureza e cultura local para um público específico, o turista.

É nesse sentido que vemos jovens como Daniela vestidas com roupas de tecido africano, espetáculos de música e dança que misturam sons locais e tradicionais com coreografias e ritmos da África Ocidental, a veiculação de estilos de música e dança como o funaná e o batuque da ilha de Santiago (considerada a mais africana) cada vez mais presentes nas atrações culturais da Boa Vista como representantes da "cultura cabo-verdiana". ${ }^{24}$ É, contudo, nas lojas de suvernires que vemos as imagens de África surgirem com toda a sua força no contexto do turismo local. 

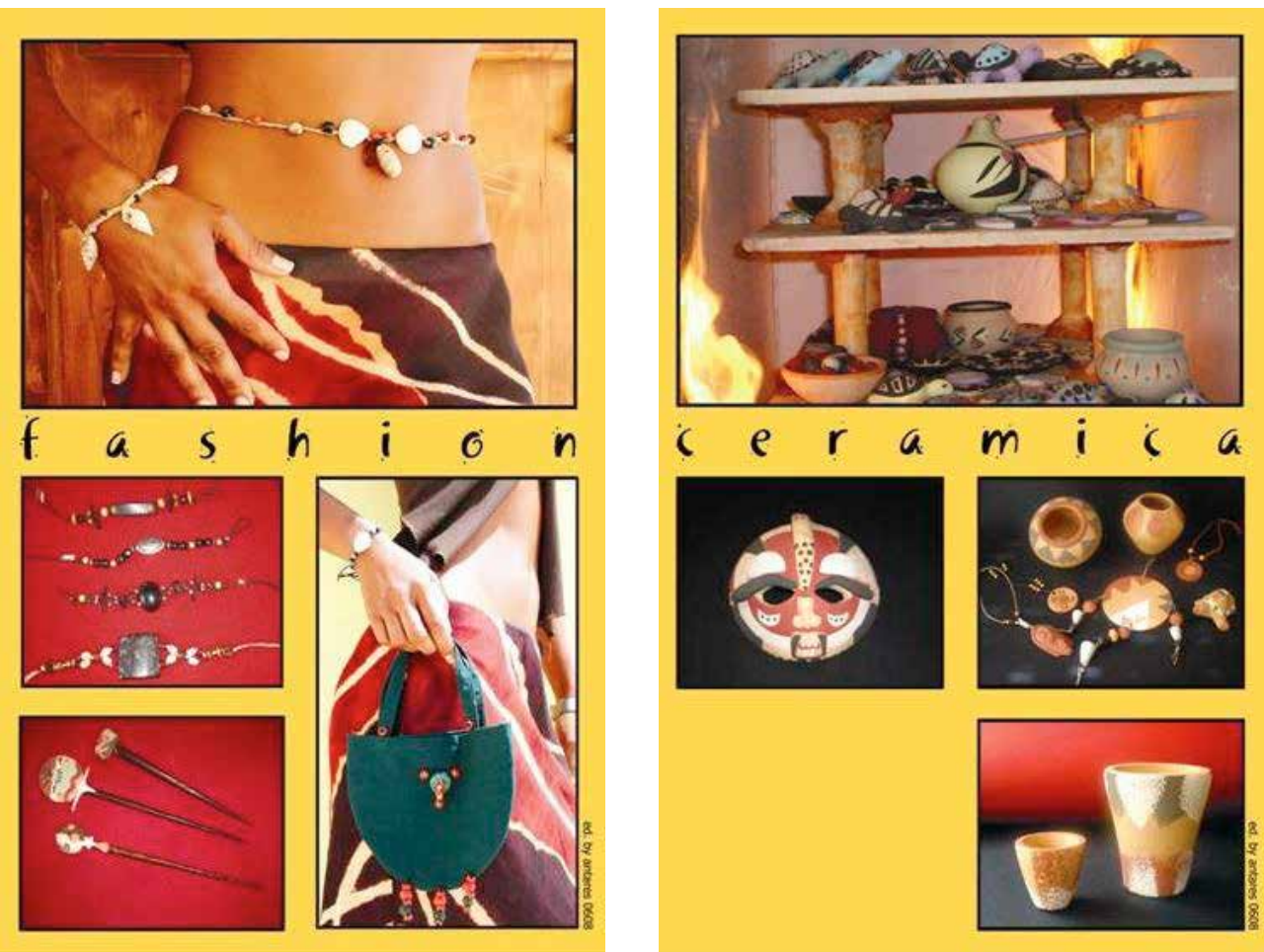

Fonte: Artesanato Di Terra (site)

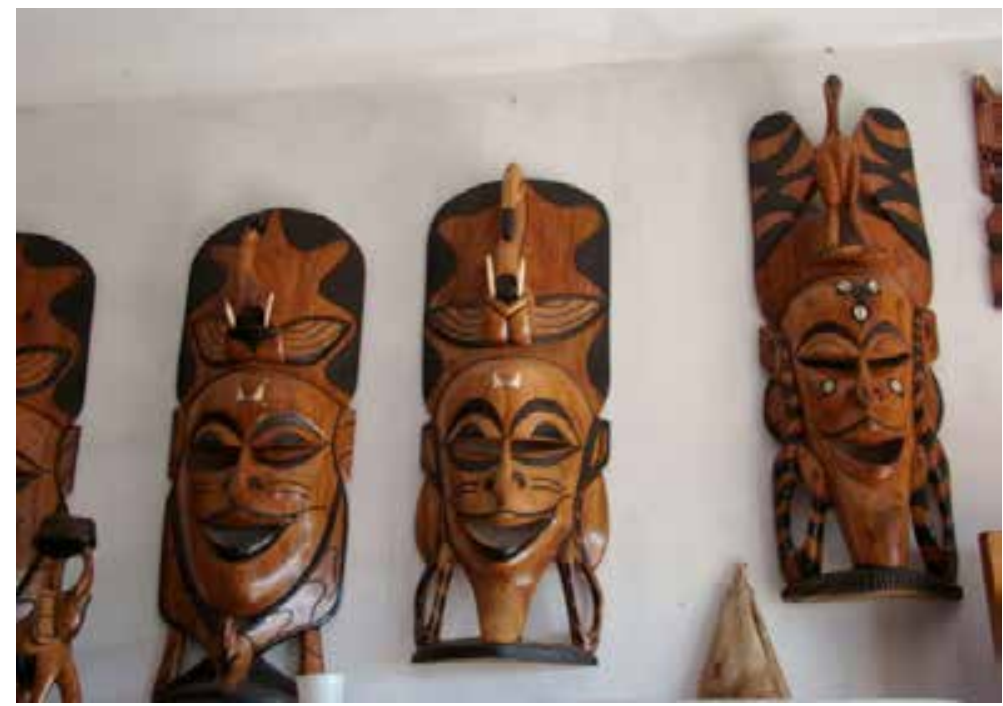

Barraca com artesanato africano

Foto de Andréa Lobo 


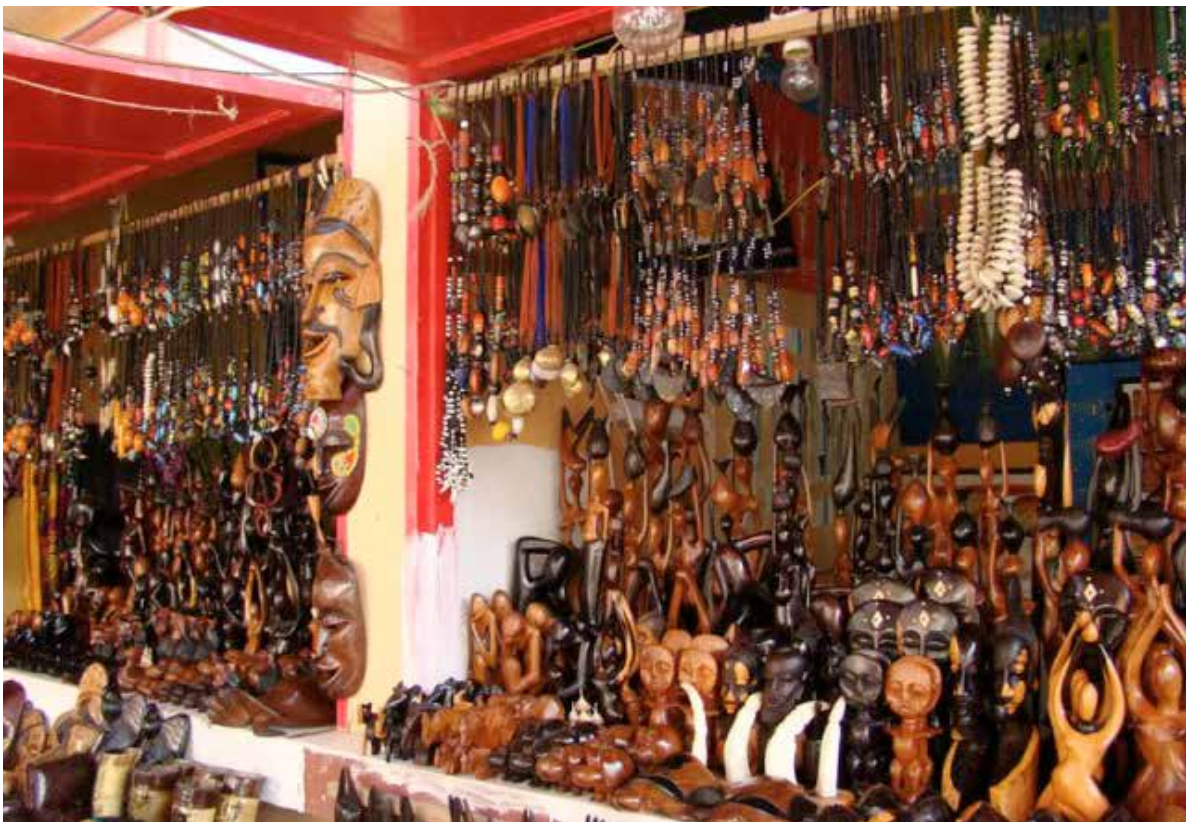

Barraca com artesanato africano

Foto de Andréa Lobo

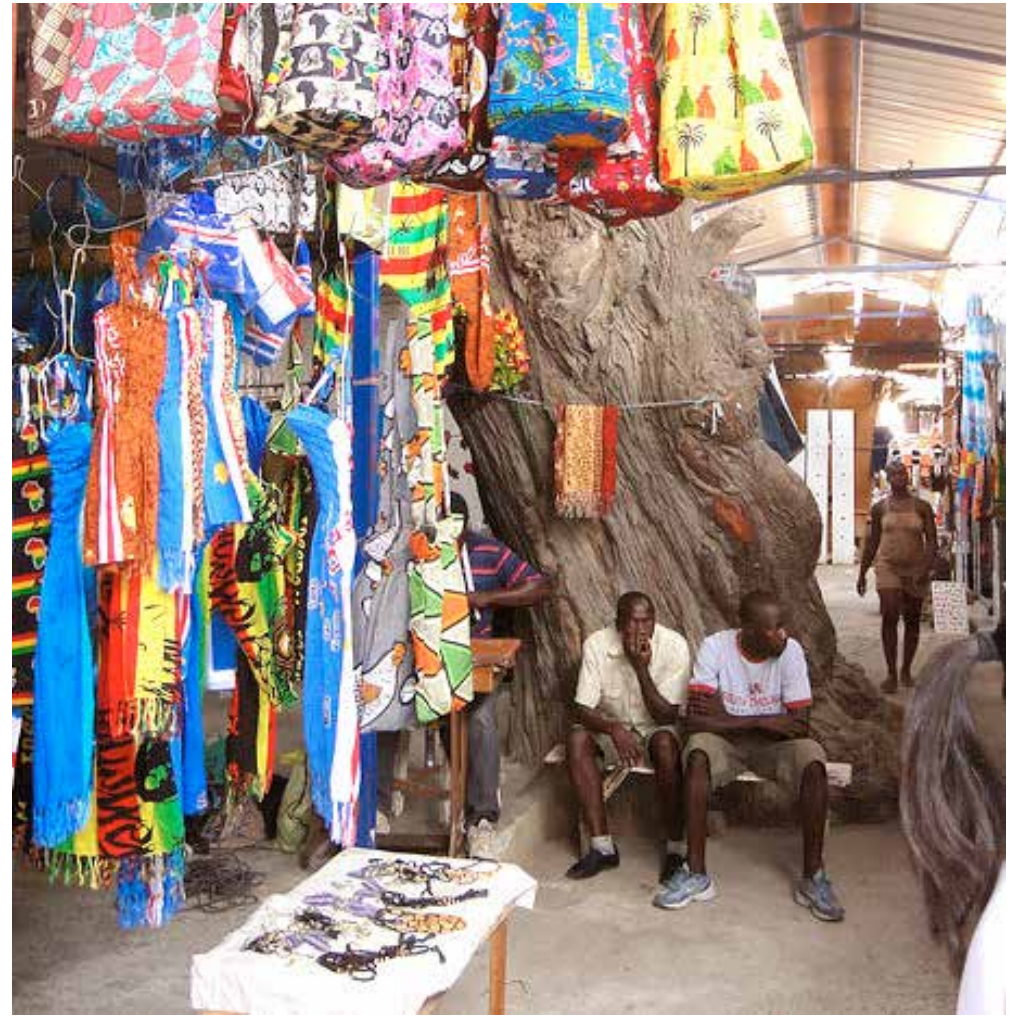

Barraca de guineenses no Mercado de Sucupira, Cidade da Praia 
Kasfir (I999) afirma que os suvenires são objetos que sintetizam a autenticidade do encontro entre o viajante e o romantizado nativo. Para o autor, após o fim da viagem os suvenires são a lembrança ou fragmentos da experiência vivida, são referências metonímicas de uma vivência cultural mais ampla que será lembrada e objetificada. Enquanto um token de lembrança de uma pessoa, de um lugar ou um evento, tais objetos têm ainda uma dimensão compartilhada, ou seja, o significado social do suvenir é partilhado entre quem vende, quem compra e quem o vê. Nesse sentido, é um poderoso marcador da experiência vivida e da qual se deve levar, guardar e partilhar lembranças.

Entendendo a importância dos suvenires no mercado turístico, em Cabo Verde (para além das lojas nos hotéis) muitos empreendedores locais têm investido em pequenas lojas de artesanato que comercializam algum artesanato local e muitos objetos que não poderiam ser classificados como genuinamente cabo-verdianos, mas sim, africanos. São panos, estátuas máscaras, colares, brincos, braceletes e demais bugigangas oriundos dos mais diversos países do continente, mas prioritariamente daqueles da África Ocidental.

E esses objetos não seguem para Cabo Verde sozinhos, guineenses, senegaleses, nigerianos e outros povoam as feiras e as ruas de Cabo Verde vendendo a arte africana para turistas (Jung, 20I3; Rovisco, 2017). Em trabalho recente Rovisco analisa mais especificamente a questão do comércio do artesanato oriundo do continente africano para turistas dessa ilha, as tensões e discriminações ${ }^{25}$ inerentes a esse contexto e os processos de (re)construção de Cabo Verde como nação. Tal como ressaltado pela autora, a presença desses africanos de origens diversas é fundamental para a dinâmica do turismo na ilha, uma vez que são eles os responsáveis pela venda e fornecimento de artesanato africano vendido como suvenires para os turistas.

Apesar das queixas dos boa-vistentes de que os "africanos" espantam os turistas com seu assédio e obscurecem o artesanato local, ${ }^{26}$ além das elaborações sobre como a chegada desses outros trouxe para a ilha só "coisas ruins" descaracterizando-a como ilha pacata e hospitaleira (Lobo, 20I4), fato é que a presença de seu artesanato atende às expectativas de turistas europeus que pouco sabem distinguir um senegalês de um cabo-verdiano, bem como suas artes. Levanto a hipótese de que, em um ambiente em que europeus vão buscar o exótico, os imigrantes de países como Senegal e outros, mediados pelos produtos trazidos de seus países de origem e vendidos para os turistas, representariam o valor de ser da África nessa sua parte que se pretende tão pouco africana.

\section{ENCONTRANDO A ÁFRICA PERDIDA}

Parte da bibliografia sobre turismo centra na descrição da relação entre turista e a população local como efêmera e geralmente resumida à questão de merca- 
do, em que os turistas são consumidores, e os locais, fornecedores de bens e serviços (ver Cohen, I984; Smith, I989, Crick, I989). O encontro poderia ser classificado como essencialmente transitório e assimétrico. A efemeridade das relações propiciaria a exploração, o engano e a desonestidade que seriam moeda corrente na relação entre turistas e população local, justamente porque nenhuma das partes envolvidas se sentiria comprometida com as consequências de sua ação (Cohen, I984: 379) numa espécie de versão globalizada da "reciprocidade negativa" analisada por Sahlins (1974) em Stone age economics.

Outros estudos (Nash, I996; Bindá, I995; Chambers, I997) mostram que o relacionamento turístico é mais complexo. Como toda relação humana em sociedade, tem um importante grau de imprevisibilidade, não podendo ser generalizado e nem predeterminado por modelos genéricos. As reações de turistas e populações locais podem ser diversas, ainda que em uma cultura pensada como relativamente unificada. ${ }^{27}$

Sob um ponto de vista mais positivo, o turismo pode ser percebido como um encontro que tem o poder de mudar perspectivas preexistentes (Bindá, I 995; Chambers, I997), promovendo formas diferenciadas de relações, de conceber e atuar sobre espaços, formas com as quais as populações que ocupam pontos de atração turística passam a ter que negociar. Permeado por formas discursivas que "fazem" o lugar enquanto mercadoria, a entrada no mercado produz não somente imagens do lugar para um público externo, mas discursos e práticas apropriados pela população num processo de valorização do local que acaba por reconfigurar identidades, além de atrair novos atores, então incorporados num programa de criação de infraestruturas que viabilizem tal projeto.

Muito além de novas perspectivas econômicas e de desenvolvimento, o turismo (re)cria percepções diferenciadas da realidade, novos costumes, valores e formas de vida que redimensionam as práticas sociais, e a população local longe está de ser vítima de todo esse contexto. Como afirma Bruner (2009), as identidades não são dadas nesse processo, são performadas por pessoas com agência e que têm escolhas. Por outro lado, as fronteiras não são fixas, turistas e nativos invadem os espaços uns dos outros criando campos de interação nem sempre previstos e controláveis.

E nesse cenário de (auto)promoção do país no mercado turístico internacional, no qual empresários, imigrantes e também cabo-verdianos reelaboram as representações sobre Cabo Verde, podemos observar as novas facetas da tensão identitária que marca a formação dessa nação: mais uma vez os ilhéus se veem perante as duas matrizes, africana e europeia, e mais uma vez as ambiguidades de ser e não ser África ocupam um lugar estratégico em sua representação por um olhar externo e em sua autorrepresentação para um outro.

Alguns pesquisadores têm argumentado que a nação cabo-verdiana sofre de uma "esquizofrenia identitária" expressa nas ambivalências que têm marcado as relações de Cabo Verde com o continente africano e resulta de um longo pro- 
cesso de internalização e posterior externalização de um habitus que, ao mesmo tempo em que afirma sua especificidade e seu cosmopolitismo, enfatiza sua aproximação cultural com o Ocidente e recusa sua inserção cultural e identitária em África (Furtado, 2013; Anjos, 2003). Tais autores, apesar de sinalizar que o movimento pendular ora em direção à Europa, ora em direção à África seria a marca dessa "esquizofrenia", pouco exploram em suas análises os momentos da história do arquipélago em que há uma aproximação positiva com o continente. Segundo sua perspectiva, a mestiçagem como marca fundamental do cabo-verdiano que o aproxima do Ocidente negaria ou invisibilizaria a condição negro-africana.

De minha parte, penso ser produtivo ficar com a ideia de ambiguidade em sua forma mais plena. Como afirma Vasconcelos (2007), no decurso das transformações políticas que marcaram o século XX no arquipélago, o estereótipo positivamente valorado foi ora europeu, ora africano, ou seja, ambos estiveram presentes na consciência da cabo-verdianidade, ambos foram internalizados em Cabo Verde. Certa vez, em conversa com um intelectual cabo-verdiano ele me relatou que a própria representação cartográfica do arquipélago ao longo de sua história materializou tal elemento estruturador da cultura local, estando localizado geograficamente mais próximo ou mais distante dos continentes, ao sabor dos desejos dos cartógrafos e dos interesses políticos de então.

Toda essa discussão reaparece no discurso turístico de maneira estratégica, menos como um dilema e mais como um atributo a ser devidamente explorado (ou vendido) na construção do país no concorrido mercado turístico global. Ser e não ser África são atributos que jogam a favor do arquipélago tanto nos discursos dos operadores turísticos quanto nas práticas locais de autorrepresentação. Indo além, essa ambiguidade é também apropriada pelo turista, que pode desfrutar tanto das características intrínsecas de viajar para ilhas paradisíacas perdidas em pleno oceano Atlântico, mas não tão perdidas assim, pois logo ali está o continente africano com todo seu exotismo, que, se não vivido plenamente em um pedaço de África tão pouco africano, pode ser levado na bagagem como um suvenir, uma lembrança de ter estado em África... mas não muito!

Recebido em 2I/7/20I7 | Revisto em 3/5/20I8 | Aprovado em 9/5/2018

Andréa Lobo é doutora em antropologia social, professora da Universidade de Brasília, pesquisadora e coordenadora do Laboratório de Estudos em Etnologia em Contextos Africanos (Ecoa). Realiza pesquisa em Cabo Verde desde o final da década de I990. É autora de Tão longe, tão perto: famílias e movimentos na ilha de Boa Vista de Cabo Verde (20I4) e de diversos artigos sobre as dinâmicas de mobilidade e formas familiares a partir da sociedade cabo-verdiana. 


\section{NOTAS}

I Agradeço os pareceres recebidos, com comentários e sugestões que, certamente, em muito contribuíram para adensar a análise. Agradeço ainda, aos colegas Antonio Motta e Wilson Trajano Filho pela leitura e sugestões.

2 Em I986 além de outros prêmios, o filme ganhou sete Oscars (melhor filme, melhor diretor, melhor roteiro adaptado, melhor fotografia, melhor trilha sonora original, melhor direção de arte e melhor som) e foi indicado em mais quatro categorias: melhor ator coadjuvante (Klaus Maria Brandauer), melhor atriz (Meryl Streep), melhor figurino e melhor edição.

3 Entre outros prêmios, em 2002 a produção ganhou o Oscar de melhor filme estrangeiro.

4 Aos interessados em reflexões sobre turismo e etnicidade, recomendo o artigo de Dean MacCannell (I984).

5 Para mais detalhes sobre tais destinos no contexto do turismo internacional, ver Crick (I989).

6 Ver interessante reflexão sobre o artesanato e o suvenir africano no contexto turístico de Cabo Verde em artigo de Eduarda Rovisco (2017).

7 O caso dessa ilha, de sua transição de ilha periférica para o lugar central que ocupa hoje no turismo nacional será tratado no próximo tópico.

8 Em uma pesquisa inicial encontrei mais três trabalhos sobre essa temática para o país. Ver Amarante, 20I2, Mota 2014 e Rovisco, 2017.

9 De acordo com dados do Instituto Nacional de Estatística (INE), entre 2000 e 2015, o número de pessoas que deram entrada em hotéis no país teria passado de 145.076 para 569.387 (INE, 2005 e 20I6).

Io Realizei pesquisa na ilha da Boa Vista sobre dinâmicas familiares e mobilidades em 2004 e 2005. Na ocasião refleti sobre os impactos do turismo no contexto local bem como as relações afetivo-conjugais entre cabo-verdianos e europeus no âmbito do turismo (Lobo, 20I4). Parte dos dados que aqui apresento é oriunda dessa pesquisa, sendo complementada pelo acompanhamento que venho realizando em visitas de campo periódicas ao arquipélago de 
inícios da década de 20 Io até o presente momento (vou ao menos uma vez por ano a Cabo Verde desde então). O acompanhamento das dinâmicas turísticas por meio das redes sociais e de sites sobre a ilha da Boa Vista e as demais também constituem valiosas fontes de dados que exploro na presente reflexão.

I I Em referência ao título do livro de Germano Almeida, escritor e poeta cabo-verdiano nascido na Boa Vista.

I2 A Revista Fragata, da qual foi extraído o texto em epígrafe, é a revista de bordo da companhia aérea cabo-verdiana TACV. A edição citada é dedicada ao tema "Cabo Verde o país turístico", tendo sido dada atenção especial à ilha da Boa Vista.

I3 Fonte:http://www.riu.com/pt/Paises/cabo-verde/boa-vista/clubhotel-riu-karamboa/

I4 Fonte:http://www.riu.com/pt/Paises/cabo-verde/boa-vista/hotel-riu-touareg/index.jsp

I5 Considerando as proporções populacionais da ilha (cerca de I I.00o habitantes conforme o censo de 2010 e I4.45I em 2015 - dados do INE), o tamanho dos empreendimentos é algo a considerar. Cabe lembrar que até 2000 os censos registravam na Boa Vista população estável na ordem de cinco mil habitantes (o censo de 2000 registrou 4.209 residentes). O rápido e alto aumento populacional (consideravelmente maior que a média nacional para o período) tem relação direta com os fluxos de imigrantes nacionais, oriundos de Santiago, Santo Antão e outras ilhas, e internacionais, constituído por jovens (especialmente homens) vindos de Guiné-Bissau, Senegal e demais países-membros da Comunidade Econômica dos Estados da África Ocidental (Cedeao). Os senegaleses estariam amplamente envolvidos com a venda de artesanato africano para turistas. Tal como apontam Jung (20I3) e Rovisco (20I7) a dinâmica demográfica da ilha guarda estreita relação com o crescimento do turismo.

I6 Em outro momento pretendo refletir com mais vagar sobre as relações afetivas entre locais e turistas, trata-se de tema relevante e que merece ser tratado em toda a sua complexidade.

I7 Como mencionado por Bruner (2009), aqui também as apresentações de danças tradicionais são seguidas pelo 
convite para que os turistas se juntem aos locais na tentativa de aprender passos básicos dos ritmos cabo-verdianos.

I8 Juntam-se aos boa-vistenses outros grupos de jovens trabalhadores vindos da ilha do Sal e de São Vicente que já possuem experiência no ramo do turismo e vão para Boa Vista complementar a mão de obra local nesse setor.

I9 Cabe aqui uma reflexão sobre o lugar de outro outsider, o antropólogo. Ao retomar o diário de campo encontrei a seguinte passagem: "Após dias envolta neste ambiente, a hora da partida doeu em meu coração. Deixar os já amigos, o clima de festa e a beleza da vida em uma localidade com menos de 5.000 habitantes, mas repleta de tantos encantos, me trouxe lágrimas nos olhos quando o pequeno avião da TACV levantou suas rodas." Escrevi tais linhas quando estive na Boa Vista pela primeira vez. Agora, escrevendo sobre turismo, penso em continuidades. Ao acionar a mesma categoria "amigo", em que medida estaria eu reproduzindo imagens semelhantes de uma África exótica, imaginada e pronta a servir? Certamente, deixando de lado as ingenuidades, o lugar de outsider me coloca em relação de continuidade com imagens turísticas e coloniais. Esta nota tem por função, lembrar a mim e ao leitor que precisamos pensar sobre isso.

20 Fonte: site do Hotel Marine Club (http://www.marineclubresort.com/).

2I Fonte: http://www.independent.co.uk/travel/africa/travellers-guide-cape-verde-2 I 20058.html

22 Fonte: West Africa Travel Guide

23 "Este é o arquipélago de Cabo Verde, patrimônio natural de rara beleza, composto por praias brancas imaculadas e deserto alternando com trechos de vales verdes que se transformam gradualmente num marco turístico internacional para os amantes do relaxamento e da natureza intocada. O contato com a população nas ilhas mais pequenas é uma das formas de descobrir a alma do povo orgulhoso e digno de ser cabo-verdiano. Em Boa Vista, você pode respirar a magia da África, graças aos desertos sem limites, praias infinitas e oásis intocado, natureza pura e selvagem, em contraste com a simpatia dos seus 3.500 
habitantes concentrados na maior parte na vila de Sal Rei, a capital. Seu apelo é para os lugares onde o tempo flui pacificamente, quando as horas são marcadas pelos desejos e não pelo relógio. Cabo Verde é um lugar desafiador. As ilhas são quentes e ensolaradas durante todo o ano. As pessoas são de uma raça única - parte africana, parte portuguesa, parte de qualquer raça que teve a ousadia de pousar neste lugar isolado e ondulado desde a sua descoberta em meados do século XV. Sua história, até o final do século passado, era sombria e comovente, e as pessoas são infundidas com uma poesia e musicalidade que reflete seu passado melancólico. Em resumo, Cabo Verde não é uma nação para pessoas que esperam ser servidas com férias de sonho num prato. É para pessoas que têm um pouco do aventureiro nelas, que são curiosas sobre pessoas e lugares, que vão curtir as esquisitices que a vida na ilha pode lançar para elas. Não é apenas o mar aberto que separa Cabo Verde do resto da África Ocidental. As correntes frias, por exemplo, mantêm as temperaturas moderadas e um sistema político e econômico estável ajuda a sustentar o mais alto padrão de vida da África Ocidental. A população, que representa vários graus de herança africana e portuguesa, parecerá exuberantemente calorosa se viajar diretamente de, digamos, Grã-Bretanha, mas refrescantemente discreta se chegar de Lagos ou Dakar." (Tradução livre)

24 As especificidades de cada ilha e a oposição das mesmas em dois grupos, o de barlavento e o de sotavento, são marcadores fortes da identidade do arquipélago, podendo mesmo ser contestado o uso da categoria identidade no singular. Um forte marcador dessas diferenças está justamente na africanidade mais fortemente associada ao grupo de sotavento, do qual a ilha de Santiago faz parte. Boa Vista faz parte do grupo de barlavento.

25 Esses imigrantes são chamados pelos locais pejorativamente de mandjacos, fato que revela os discursos e atos discriminatórios dos quais esses comerciantes e trabalhadores são vítimas. Sobre tal temática ver Furtado (2012), Rocha (2009) e Gomes (2015).

26 Ver as reflexões de Rovisco (2017) sobre as dificuldades históricas de Cabo Verde nesse setor.

27 Sobre esse tema ver estudos sobre os esquimós (Smith, I989) e os índios Pataxó (Grunewald, 200I). 


\section{REFERÊNCIAS BIBLIOGRÁFICAS}

Amarante, Neusa. (20I2). Turismo cultural: as potencialidades turísticas do Pano de Terra de Santiago em Cabo Verde. Dissertação de Mestrado. Universidade do Minho.

Anjos, José Carlos Gomes dos. (2003). Elites intelectuais e a conformação da identidade nacional em Cabo Verde. Estudos Afro-Asiáticos, 25/3, p. 580-606.

Bindá, Andréa Havt. (1995). Viajar é mais. Dissertação de Mestrado. PPGS/Universidade de Brasília.

Bruner, Edward M. (2009). Culture on Tour: Ethnographies of Travel. Chicago: The University of Chicago Press.

Chambers, Erve. (ed.). (1997). Tourism and Culture, an applied perspective. New York: University of New York Press.

Cohen, Erik. (1984). The sociology of Tourism: approaches, issues and findings, Annual Review of Sociology, Io, p. 373392.

Comaroff, John L. \& Comaroff, Jean. (2009). Ethnicity, Inc. Chicago: The University of Chicago Press.

Crick, Malcolm. (I989). Representations of international tourism in the social sciences: sun, sex, sights, savings, and servility. Annual Review of Anthropology, i8, p. 307-344. Furtado, Cláudio A. (2013). Cabo Verde: dilemas étnico-identitários num território fluido. Ciências Sociais Unisinos, 49-I, p. 2-II.

Furtado, Cláudio A. (2012). As migrações da África Ocidental em Cabo Verde: atitudes e representações. Tese de Doutorado. Universidade Livre de Bruxelas/Universidade de Cabo Verde.

Gomes, Davidson. (20I5). Integração profissional dos imigrantes guineenses (Guiné-Bissau) no mercado laboral em Cabo Verde: estudo de caso dos carpinteiros na Praia. Dissertação de Mestrado. Universidade de Cabo Verde.

Grunewald, Rodrigo. (200I). Turismo e o "resgate" da cultura Pataxó. In: Banducci, Álvaro \& Barretto, Margarita (org.), Turismo e identidade local: uma visão antropológica. Campinas: Papirus, p. I27-I48.

INE - Instituto Nacional de Estatística de Cabo Verde. (2005). Estatísticas do Turismo, I999-2004. Praia, INE. 
INE - Instituto Nacional de Estatística de Cabo Verde. (s.d.a). Análise dos principais resultados do inquérito à movimentação de hóspedes em 2008. Disponível em <www.ine.cv>. Acesso em 8 jun. 2016.

INE - Instituto Nacional de Estatística de Cabo Verde. (2016). Estatísticas do Turismo, 2015. Praia, Cabo Verde.

Jung, Philipp. (2013). The dynamics of migration and their impact on the country of origin: a case study of Senegalese labour migrants on the cape Verdean island of Boa Vista and their relatives at home. Dissertação de Mestrado. ISCTE - Instituto Universitário de Lisboa.

Kasfir, Sidney L. (I999). Samburu souvenirs: representations of a land in Amber. In: Phillips, Ruth B. \& Steiner, Christopher B. (orgs.). Unpacking culture: art and commodity in colonial and postcolonial worlds. Berkeley: University of California Press, p. 67-83.

Lima, António Germano. (I999). Ilha da Boa Vista. Revista Fragata, Praia, 22.

Lobo, Andréa. (2014). Tão longe tão perto. Famílias e "movimentos" na ilha da Boa Vista de Cabo Verde. Edição revisada. EBook. Brasília: ABA Publicações.

Lobo, Andréa. (2012). Do feio ao belo. Aridez, seca, "patrimônio natural" e identidade em Cabo Verde. In: Sansone, Lívio. Memórias da África: patrimônios, museus e políticas das identidades. Salvador: ABA Publicações.

Lobo, Andréa. (200I). Seca, chuva e luta. Reconstruindo a paisagem em Cabo Verde. Dissertação de Mestrado. PPGAS: Universidade de Brasília.

MacCannell, Dean. (1984). Reconstructed ethnicity. Tourism and cultural identity in third world communities. Annals of Tourism Research, II, p. 375-39I.

Mota, Lucilene. (2014). Turismo: os segmentos de maior valor econômico para a Ilha de Santo Antão. Monografia (Licenciatura em Turismo). Instituto Superior de Ciências Económicas e Empresariais.

Nash, Dennison. (1996). Anthropology of Tourism. Oxford: Pergamon.

República de Cabo Verde. Secretariado da Cooperação e Planejamento. (I997). IV Plano Nacional do Desenvolvimento. Praia: SECP. 
Rocha, Eufemia. (2009). "Mandjakus são todos os africanus, todas as gentes pretas que vêm de África": xenofobia e racismo em Cabo Verde. Dissertação de Mestrado. Universidade de Cabo Verde.

Rovisco, Eduarda. (2017). Da resistência africanista ao souvenir africano: artesanato, nação e fantamasgoria na ilha da Boa Vista, Cabo Verde. Etnográfica, 2I/I, p. 5-26.

Sahlins, Marshall. (I974). Stone age economics. London: Tavistock.

Santos, Maria do Carmo. (2009). Turismo em Cabo Verde: um estudo exploratório. Dissertação de Mestrado. Universidade de Lisboa.

Smith, Valene. (1989). Hosts and guests: the anthropology of tourism. Philadelphia: University of Pennsylvania Press.

Trajano Filho, Wilson. (2003). Uma experiência singular de crioulização. Série Antropologia, Brasília, 343.

Urry, John. (I990). The Tourist Gaze - leisure and travel in contemporary societies. London: Sage Publications.

Vasconcelos, João. (2007). Filhos da terra, ou Lamarck em Cabo Verde. Lisboa: Instituto de Ciências Sociais. Universidade de Lisboa. 


\section{ÁFRICA... MAS NÃO MUITO! TURISMO E AFRICANIDADE EM CABO VERDE}

Resumo

O crescimento turístico observado nos últimos anos no arquipélago de Cabo Verde, particularmente na ilha da Boa Vista, é objeto de reflexão deste artigo. Meu interesse é pensar sobre os sentidos de africanidade construídos na relação entre cabo-verdianos e turistas europeus que se deslocam para o arquipélago em busca de experiências africanas em um ambiente calmo, paradisíaco, exótico e tropical. Tais categorias, que permeiam os folders, sites e revistas de turismo no arquipélago, são analisadas como formas de representação e de autorrepresentação nesse contexto relacional que a viagem turística produz.

\section{AFRICA... BUT NOT MUCH! TOURISM AND AFRICANITY IN CAPE VERDE}

Abstract

The topic explored in this article is the growth in tourism observed in recent years in the archipelago of Cape Verde, particularly on the island of Boa Vista. My interest is to reflect on the senses of Africanity built in the relationship between Cape Verdeans and European tourists who travel to the archipelago in search of African experiences in a calm, paradisiacal, exotic and tropical environment. These categories, which permeate the brochures, sites and tourism magazines in the archipelago, are analysed as forms of representation and self-representation in the relational context produced by the tourism trip.
Palavras-chave

Turismo;

África;

Cabo Verde; identidade; nação.

Keywords

Tourism;

Africa;

Cape Verde;

identity;

nation. 